\title{
ANALISIS KEPUASAN KONSUMEN TERHADAP KUALITAS PRODUK KOPI DAN KUALITAS PELAYANAN MENGGUNAKAN METODE IMPORTANCE PERFOMANCE ANALYSIS (Studi Kasus Di Geo Coffee)
}

\author{
Putu Anggi Ranitaswari ${ }^{1}$, Sri Mulyani ${ }^{2}$, Cokorda Anom Bayu Sadyasmara ${ }^{2}$ \\ ${ }^{1}$ Mahasiswa Jurusan Teknologi Industri Pertanian, Fakultas Teknologi Pertanian, UNUD \\ ${ }^{2}$ Dosen Jurusan Teknologi Industri Pertanian, Fakultas Teknologi Pertanian, UNUD \\ E-mail koresponden: srimulyani@unud.ac.id
}

\begin{abstract}
This study aims to determine the attributes that are considered important by consumers in order to achieve customer satisfaction, know the level of satisfaction or level of consumer suitability of products and services in Geo Coffee, and determine the attributes that need to get priority from the company to be improved in order to achieve customer satisfaction. This research was conducted at Geo Coffee. The sample used was 91 respondents using epurposive sampling method. Data were obtained by distributing questionnaires and correspondents directly. This research uses Importance Performance Analysis method. The result of this research shows that attribute with highest level of consumer satisfaction for product quality is characteristic of coffee taste characteristic based on brand cafe with level of matching equal to $101.95 \%$. the attribute with the lowest level of conformity is a constant (stable) coffee taste for each presentation corresponding to a suitability level of $82.52 \%$. Attributes with the highest level of customer satisfaction for service quality is the speed in responding to complaints and customer problems with a level of suitability of $120.34 \%$. The attribute with the lowest level of customer satisfaction for service quality is the waiter providing services and appropriate handling to customer needs with the level of suitability of $80.05 \%$. The attributes that must be prioritized for the product are the constant (stable) coffee taste of each serving and the sweet taste of coffee. The attributes that must get priority for service is the process of making order menu in Geo Coffee done quickly.
\end{abstract}

Keywords: customer satisfaction, Importance Performance Analysis, Geo Coffee

\section{PENDAHULUAN}

Kopi merupakan salah satu minuman yang sangat di gemari oleh masyarakat Indonesia karena rasa dan aromanya. Minuman ini di gemari oleh segala umur secara turun temurun (Haryanto 2012). Komponen yang terdapat pada kopi adalah kafein, kaffeol, trigonelin, asam amino, karbohidrat, asam alifatik, asam chlorogenat, lemak, mineral, komponen volatil, dan komponen karbonil. kafein yang terdapat dalam kopi merupakan stimulan dari sistem saraf pusat sehingga dapat meningkatkan kinerja otak (Panggabean, 2011). Kopi saat ini dijuaal bukan hanya sebagai sebuah produk, namun juga bagian dari life sytle seiring dengan banyak berkembangangnya coffee shop atau kedai kopi.

Bentuk kedai kopi modern sangat beragam, dari kedai kopi yang terkesan eksklusif hingga kedai kopi yang standar. Kedai-kedai tersebut tentunya memiliki ciri khas tersendiri, mulai dari konsep tempat, konsep penjualan, konsep kemasan, konsep menu, hingga konsep pelayanan yang menarik. Kombinasi dari beberapa faktor tersebut kemudian menjadi daya tarik bagi para konsumen. Geo Coffee adalah salah satu tempat pengolahan kopi sekaligus coffee shop yang berlokasi di daerah Kerobokan Kelod Utara, Kabupaten Badung. Kopi yang diolah dan disajikan di Geo Coffee didatangkan langsung dari petani yang berasal dari Plaga, Kintamani, Gitgit, Pupuan. Jenis kopi yang di gunakan adalah kopi Robusta dan Arabica. Biji Kopi ini diolah langsung di Geo Coffee mulai dari proses penyangraian hingga penyeduhan yang di sajikan untuk konsumen. Geo coffee menjual kopi dalam 3 bentuk yaitu biji yang sudah di sangrai, biji yang sudah di giling (bubuk), dan kopi yang di minum langsung di tempat.

Berdasarkan survei awal, diketahui bahwa rata-rata kunjungan konsumen ke Geo Coffee adalah sebanyak 1000 konsumen perbulan. Jumlah tersebut masih belum mencapai target perusahaan, 
karena perusahaaan ini baru beroperasi di bulan februari 2017. Manajemen Geo Coffee ingin mengukur tingkat kepuasan konsumennya melalui tingkat kinerja produk dan pelayanan sehingga dalam rangka meningkatkan kunjungan dan penjualan. Beberapa metode dapat digunakan untuk mengukur tingkat kepuasan konsumen, antara laina adalah Structural Equation Modeling (SEM), Importance Performance Analysis (IPA), Customer Satisfaction Index (CSI) dan metode-metode lainnya. Metode Importance Performance Analysis (IPA) adalah metode yang paling umum digunakan untuk mengukur tingkat kepuasan konsumen karena memiliki beberapa kelebihan dibandingkan dengan metode lain. Kelebihan tersebut antara lain dapat menunjukkan atribut produk/jasa yang perlu ditingkatkan ataupun dikurangi untuk menjaga kepuasan konsumen, hasilnya relatif mudah diinterpretasikan, skalanya relatif mudah dimengerti, dan membutuhkan biaya yang rendah (Dian, 2014).

Berdasarkan hal tersebut maka penelitian mengenai kepuasan konsumen terhadap kualitas produk dan pelayanan di Geo Coffee perlu dilakukan untuk mengidentifikasi faktor-faktor yang perlu diperhatikan dalam rangka meningkatkan kualitas produk dan kualitas layanan, sehingga didapatkan gambaran utuh posisi atau kinerja Geo Coffee saat ini. Adapun tujuan dari penelitian ini adalah (1) mengetahui atribut-atribut produk dan pelayanan yang dianggap penting oleh konsumen, (2) mengukur tingkat kinerja produk dan pelayanan di Geo Coffee, (3) mengukur tingkat kepuasan konsumen terhadap produk dan pelayanan di Geo Coffee dan (4) menentukan atribut-atribut apa yang perlu mendapatkan prioritas dari perusahaan berdasarkan tingkat kepentingan dan kinerja untuk memberikan kepuasan terhadap konsumennya.

Kualitas produk dan pelayanan yang baik di dalam suatu perusahaan, akan menciptakan kepuasan bagi para konsumennya. Setelah konsumen merasa puas dengan produk atau pelayanan yang diterimanya, konsumen akan membandingkan produk dan pelayanan yang diberikan. Apabila konsumen benar-benar puas, mereka akan membeli ulang serta memberi rekomendasi kepada orang lain untuk membeli di tempat yang sama (Tjiptono, 2012).

\section{METODELOGI PENELITIAN}

Penelitian ini dilaksanakan di Geo Coffee yang berlokasi Di Jalan Pengubengan Kauh No.94, Kerobokan Kelod Utara, Kabupaten Badung. Waktu penelitian dilaksanakan dari bulan November Desember 2017. Jumlah responden di tentukan sebanyak 91 orang berdasarkan Metode Slovin dengan tingkat kesalahn 10\%. Jumlah responden yang dipilih sudah sesuai dengan standar statistik bahwa jumlah sampel minimum adalah lebih besar dari atau sama dengan $30(n \geq 30)$. (Kerlinger dan Lee, 2000).

berdasarkan Metode Slovin dengan rumus:

$$
\begin{aligned}
& \mathbf{n}=\frac{\boldsymbol{N}}{1+\mathrm{N}^{2} \mathrm{c}^{\mathbf{x}}} \\
& \text { Dimana, } \\
& \mathrm{n}=\text { ukuran sampel } \\
& \mathrm{e}=\text { nilai kritis/batas kelonggaran ketidaktelitian karena kesalahan pengambilan sampel } \\
& \text { populasi. } \\
& \mathrm{N}=\text { ukuran populasi }
\end{aligned}
$$

Dalam penelitian ini uji reliabilitas dilakukan menggunakan metode Cronbach Alpha. Alat ukur dikatakan reliabel jika menggunakan koefisien Cronbach Alpha menyatakan bahwa harus lebih besar dari 0.60. Dalam penelitian ini pengukuran validitas kuesioner menggunakan teknik Product Moment. Apabila r product moment lebih besar dari nilai korelasi pada tabel angka kritik nilai $\mathrm{r}$ berarti korelasi antara X dan Y adalah konsisten dan reliabel serta valid untuk digunakan (Ghozali, 2005).

Penelitian tahap pertama yang dilakukan adalah penentuan dan penggolongan atribut-atribut kepuasan konsumen untuk produk dan layanan, serta penyusunan kuesioner. Setelah menyusun kuesioner, dilakukan pengujian reliabilitas dan validitas terhadap kuesioner tersebut. Pengujian reliabilitas dan validitas ini sangat penting dilakukan karena bertujuan untuk mengetahui sejauh mana suatu alat ukur dapat dipercaya serta sejauh mana alat ukur dapat mengukur yang ingin diukur. Apabila setelah diuji kuesioner ternyata tidak reliabel dan tidak valid, maka dilakukan revisi terhadap 
kuesioner dan pengujian kembali. Apabila kuesioner yang telah diuji ternyata reliabel dan valid maka penelitian dilanjutkan ke tahap selanjutnya yaitu penentuan populasi dan sampel menggunakan metode Slovin.Selanjutnya data dikumpulkan dan dianalisis menggunakan program SPSS dan Microsoft Excel. Setelah analisis data, akan didapatkan atribut-atribut yang dianggap penting, atribut prioritas serta tingkat kepuasan konsumen terhadap produk dan pelayanan.

\section{HASIL DAN PEMBAHASAN}

\section{Gambaran Umum Perusahaan}

Geo Coffee mulai beroperasi pada bulan Februari 2017, Geo Coffee di dirikan oleh Bapak I Made Suarnatha merupakan pemilik dari Geo Coffee. Geo Coffee merupakan sebuah tempat pengolahan kopi yang berlokasi di Jalan Pengubengan Kauh no. 94, Kerobokan Kelod Utara, Kabupaten Badung. Geo Coffee berdiri pada bulan Oktober 2016, bisnis yang dikelola Yayasan Wisnu. Geo Coffee mempunyai 3 barista, 4 waiters. Dengan jumlah pegawai yang ada, pengelola kafé mengharapkan agar para konsumen mendapatkan pelayanan yang maksimal.

\section{Analisis Reliabilitas dan Validitas}

Analisis reliabilitas dan validitas pada penelitian ini di lakukan di Papilas Coffee House di jalan Ngurah Rai No. 27, Semarapura Tengah, Klungkung. Penelitian ini menggunakan 30 orang sebagai responden. Hasil uji reliabilitas kuesioner kepentingan produk didapatkan koefisien Cronbach Alpha $(\alpha)$ sebesar 0,818 sehingga bisa dikatakan item pertanyaan pada kuesioner reliabel kinerja produk didapatkan sebesar 0,772 sehingga item pertanyaan pada kuesioner reliabel (Ghozali, 2005).

Hasil uji reliabilitas kuesioner kepentingan pelayanan didapatkan koefisien Cronbach Alpha $(\alpha)$ sebesar 0,880 sehingga bisa dikatakan item pertanyaan pada kuesioner reliabel karena memiliki koefisien Cronbach Alpha $(\alpha)$ yang menyatakan bahwa harus lebih besar dari 0,60. Untuk koefisien Cronbach Alpha $(\alpha)$ kuesioner kinerja pelayanan didapatkan sebesar 0,873 sehingga bisa dikatakan item pertanyaan pada kuesioner reliabel (Ghozali, 2005).

Hasil uji validitas kuesioner untuk tingkat kepentingan dan tingkat kinerja pelayanan, didapatkan bahwa nilai $r$ setiap pernyataan pada kuesioner menunjukkan di atas nilai $r$ tabel $(\alpha=0.05)$ sebesar 0.361. Hal ini berarti setiap pernyataan yang terdapat pada kuesioner dianggap valid untuk digunakan (Ghozali, 2005).

\section{Analisis Atribut yang Dianggap Penting oleh Konsumen}

Atribut yang dianggap penting oleh konsumen didapatkan dengan cara menghitung jumlah skor setiap atribut. Semakin besar jumlah skor setiap atribut maka bisa dikatakan semakin besar pula tingkat kepentingan atribut tersebut. derajat kepentingan untuk produk dan pelayanan dapat dilihat pada Tabel 1 dan 2.

Tabel 1. Penilaian responden terhadap tingkat kepentingan atribut produk di Geo Coffee

\begin{tabular}{clc}
\hline No & \multicolumn{1}{c}{ Atribut } & Skor \\
\hline 1 & Konsistensi rasa kopi setiap penyajian & 428 \\
2 & Formulasi rasa kopi & 420 \\
3 & Aroma kopi & 410 \\
4 & Rasa kopi seimbang antara pahit, manis, dan asam & 349 \\
5 & Rasa kopi bertahan lama di rongga mulut setelah & \\
& meminum & 346 \\
\hline
\end{tabular}

Berdasarkan hasil penelitian menunjukan bahwa atribut dengan skor terbesar adalah konsistensi rasa kopi setiap penyajian dengan total skor 428. Atribut rasa secara keseluruhan hampir selalu menjadi atribut yang paling penting karena rasa dari sebuah produk merupakan gambaran atau citra utama dari kualitas sebuah produk. Hasil serupa juga diperoleh pada penelitian Qomariah dkk (2014) tentang atribut kopi bubuk Sido Luhur, atribut ini menjadi atribut yang paling 
penting dengan skor 463. Atribut dengan skor terkecil adalah rasa kopi bertahan lama di rongga mulut setelah meminum dengan total skor 346, hal ini mungkin disebabkan karena konsumen masih mengabaikan faktor ciri khas aroma dari kafe, karena sudah cukup puas dengan mengkonsumsi kopi dengan rasa yang enak dan konstan.

Tabel 2. Penilaian responden terhadap tingkat kepentingan atribut pelayanan di Geo Coffee

\begin{tabular}{llc}
\hline No & \multicolumn{1}{c}{ Atribut } & \multicolumn{1}{c}{ Skor } \\
\hline 1 & Pelayan menangani konsumen sesuai kebutuhan & 418 \\
2 & Kondisi lingkungan Kafe & 417 \\
3 & Kepercayaan diri karyawan dalam melakukan pelayanan & 416 \\
4 & Kesigapan dan daya tanggap pelayan dalam memenuhi kebutuhan pelanggan & 415 \\
5 & Kecepatan waktu penyajian & 413 \\
6 & Kesungguhan dalam merespon dan melayani pelanggan & 412 \\
7 & Kemampuan dalam menjelaskan ataupun memberikan informasi yang & 410 \\
& dibutuhkan pelanggan & 409 \\
8 & Kepedulian terhadap masalah yang dialami pelanggan & 408 \\
9 & Penampilan karyawan & 406 \\
10 & Kesopanan dan keramahan karyawan dalam melayani pelanggan & 365 \\
11 & Akses internet wifi & 362 \\
12 & Ketepatan penyajian menu & 357 \\
13 & Peralatan dan pelengkapan yang digunakan sesuai standar & 355 \\
14 & Kesamaan dalam memperlakukan pelanggan & 354 \\
15 & Keamanan dan kenyamanan pelanggan pada saat berada di kafe & 353 \\
16 & Desain interior kafe & 353 \\
17 & Kemampuan komunikasi karyawan & 352 \\
18 & Pengetahuan karyawan terhadap menu ataupun produk yang ditawarkan & 349 \\
19 & Kecepatan dalam merespon keluhan dan permasalahan pelanggan & \\
\hline
\end{tabular}

Berdasarkan hasil kuisioner tingkat kepentingan atribut kepuasan konsumen untuk pelayanan, atribut dengan skor terbesar adalah pelayan menangani konsumen sesuai kebutuhan dengan total skor 418 mengindikasikan bahwa atribut mutu pelayanan Reliability (Kehandalan) menjadi perhatian utama bila dibandingkan dengan tangible (bukti fisik), Assurance (jaminan mutu), Empathy (empati) dan Responsiveness (daya tanggap). Omar dkk. (2015) menyebutkan bahwa faktor reliability sangat berhubungan erat dengan kepuasan pelanggan. Atribut dengan skor terkecil adalah kecepatan dalam merespon keluhan dan permasalahan pelanggan yakni dengan total skor 349. Konsumen mungkin menganggap cukup hanya dengan fokus terhadap pelayanan dan penanganan yang tepat, maka keluhan dan permasalahan seharusnya dapat diminimalisir.

\section{Analisis Tingkat Kinerja}

Analisis tingkat kinerja Geo Coffee dilakukan dengan cara menghitung skor penilaian setiap atribut sehingga diketahui penilaian konsumen terhadap kinerja di Geo Coffee. Semakin besar skor yang didapat, maka penilaian responden terhadap kinerja Geo Coffee semakin baik. Derajat kinerja produk dan pelayanan dapat dilihat pada Tabel 3 dan 4.

Berdasarkan hasil kuesioner tingkat kinerja untuk produk, atribut dengan skor terbesar adalah formulasi rasa kopi dengan total skor 430. Hal tersebut disebabkan oleh resep spesial yang dimiliki oleh Geo Coffee dimana kopi yang digunakan merupakan campuran jenis kopi dari beberapa tempat melalui proses dan peralatan yang baik, sehingga menghasilkan rasa yang khas. Penelitian yang 
dilakukan oleh Torey dkk. (2016) serta Damanik dkk. (2014) dengan produk sama yakni kopi, juga mendapatkan atribut rasa merupakan atribut dengan nilai kinerja tertinggi dibandingkan dengan atribut lainnya.

Atribut dengan skor terkecil rasa kopi seimbang antara pahit, manis, dan asam dengan total skor 343. Besarnya skor pada atribut ciri khas rasa ternyata tidak sejalan dengan atribut ciri khas aroma. Faktor yang mungkin menjadi penyebab adalah konsumen lebih mudah membedakan berdasarkan rasa daripada aroma. Penelitian yang dilakukan oleh Aditya dkk. (2016) terhadap karakteristik kopi mendapatkan hasil bahwasannya tidak ada perbedaan yang nyata terhadap variabel aroma kopi namun ada perbedaan yang nyata pada variabel rasa.

Tabel 3. Penilaian responden terhadap tingkat kinerja atribut produk di Geo Coffee

\begin{tabular}{clc}
\hline No & \multicolumn{1}{c}{ Atribut } & Skor \\
\hline 1 & Formulasi rasa kopi & 430 \\
2 & Rasa kopi bertahan lama di rongga mulut setelah meminum & 418 \\
3 & Aroma kopi & 412 \\
4 & Konsistensi rasa kopi setiap penyajian & 346 \\
5 & Rasa kopi seimbang antara pahit, manis, dan asam & 343 \\
\hline
\end{tabular}

Ket $:$ Skor maks $=455$ Skor $\min =91$

Berdasarkan hasil kuesioner tingkat kinerja untuk pelayanan, atribut dengan skor terbesar adalah desain interior kafe dengan total skor 421. Konsep dari desain interior Geo Coffee yang klasik, yakni dengan ornamen bambu berhasil mempengaruhi psikologis konsumen sehingga memberikan nilai kepuasan bagi konsumen. Hasil penelitian lain yang menunjukkan bahwa interior memiliki pengaruh yang positif dan signifikan terhadap konsumen adalah penelitian Lucano (2011) di Restoran Imperial Lamian Tunjungan Plaza Surabaya. Atribut dengan skor terkecil adalah kesamaan dalam memperlakukan pelanggan dengan total skor 332. Berdasarkan hal tersebut, Geo Coffee perlu meningkatkan rasa empati staf, dan juga mempertimbangkan penambahan staf waitress, karena kecilnya skor atribut ini mungkin disebabkan oleh jumlah waitress yang sedikit, sehingga pada saat kondisi ramai dan crowded, tidak terjadi kebingunan dalam melayani konsumen yang dapat menimbulkan persepsi perbedaan dalam pelayanan.

Tabel 4. Penilaian responden terhadap tingkat kinerja pelayanan di Geo Coffee

\begin{tabular}{llc}
\hline No & \multicolumn{1}{c}{ Atribut } & Skor \\
\hline 1 & Desain interior kafe & 421 \\
2 & Kecepatan dalam merespon keluhan dan permasalahan pelanggan & 420 \\
3 & Kondisi lingkungan kafe & 419 \\
4 & Pengetahuan karyawan terhadap menu ataupun produk yang & 414 \\
& ditawarkan ditawarkan & \\
5 & Akses internet wifi yang baik & 413 \\
6 & Kemampuan komunikasi karyawan & 413 \\
7 & Kesungguhan dalam merespon dan melayani pelanggan & 412 \\
8 & Penampilan karyawan & 410 \\
9 & Kepedulian terhadap masalah yang dialami pelanggan & 409 \\
10 & Ketepatan penyajian menu & 399 \\
11 & Peralatan dan pelengkapan yang digunakan sesuai standar & 338 \\
12 & Kesopanan dan keramahan karyawan dalam melayani pelanggan & 336 \\
13 & Kecepatan waktu penyajian & 335 \\
14 & Kesigapan dan daya tanggap pelayan dalam memenuhi kebutuhan & 335 \\
\hline
\end{tabular}




\begin{tabular}{lll}
\hline & pelanggan & \\
15 & Pelayan menangani konsumen sesuai kebutuhan & 334 \\
16 & Keamanan dan kenyamanan pelanggan pada saat berada di kafe & 334 \\
17 & Kepercayaan diri karyawan dalam melakukan pelayanan & 333 \\
18 & Kemampuan dalam menjelaskan ataupun memberikan informasi yang & 333 \\
& dibutuhkan pelanggan & 332 \\
\hline
\end{tabular}

Ket : Skor maks $=455$ Skor $\min =91$

\section{Analisis Tingkat Kepuasan Konsumen Geo Coffee}

Skor kinerja dan skor kepentingan dapat membentuk kepuasan, karena kepuasan merupakan kesesuaian antara kinerja perusahaan yang diterima konsumen dengan harapan yang diinginkan konsumen (Ainy dkk, 2012). Untuk tingkat kepuasan atau tingkat kesesuaian, jika persentase yang didapatkan antara 80-100\% maka dapat dikatakan kinerja dari masing-masing atribut telah memenuhi kepentingan konsumen namun masih perlu dilakukan perbaikan lagi, sedangkan jika persentase yang didapatkan lebih dari $100 \%$ maka dapat dikatakan kinerja dari atribut tersebut telah melebihi kepentingan konsumen (Lodhita 2014). Hasil penilaian responden terhadap tingkat kepentingan dan tingkat kinerja serta tingkat kepuasan untuk produk dan pelayanan di Geo Coffee dapat dilihat pada Tabel 5 dan 6.

Tabel 5. Penilaian responden terhadap tingkat kepentingan (Y) dan tingkat kinerja (X) serta tingkat kepuasan (TKi) produk Geo Coffee

\begin{tabular}{|c|c|c|c|c|c|c|}
\hline No & Atribut & $\mathrm{Xi}$ & $\bar{X}$ & Yi & $\bar{Y}$ & $\begin{array}{l}\text { Tki } \\
(\%)\end{array}$ \\
\hline 1 & Aroma kopi & 418 & 4.59 & 410 & 4.51 & 101.95 \\
\hline 2 & $\begin{array}{l}\text { Rasa Kopi seimbang antara pahit, } \\
\text { manis, dan asam }\end{array}$ & 343 & 3.77 & 349 & 3.84 & 98.28 \\
\hline 3 & Formulasi rasa kopi & 412 & 4.27 & 420 & 4.35 & 98.21 \\
\hline 4 & Rasa kopi & 334 & 4.53 & 344 & 4.62 & 98.10 \\
\hline \multirow[t]{2}{*}{5} & $\begin{array}{l}\text { Konsistensi rasa kopi setiap } \\
\text { penyajian }\end{array}$ & 346 & 3.74 & 428 & 4.53 & 82.52 \\
\hline & & & & & 4,37 & 95,72 \\
\hline
\end{tabular}

Tabel 5 menunjukkan bahwa aroma kopi dengan tingkat kesesuaian sebesar 101,95\% yang berarti kinerja Geo Coffee melebihi kepentingan konsumen. Penelitian Rahayu (2011) juga memperoleh hasil yang serupa dimana atribut yang memiliki tingkat kesesuaian tertinggi adalah karakter rasa pada kopi memiliki ciri khas yang tinggi. Atribut dengan tingkat kesesuaian terendah adalah konsistensi rasa kopi setiap penyajian dengan tingkat kesesuaian sebesar 82,52\% yang berarti kinerja Geo Coffee sudah baik namun perlu diperbaiki karena belum sesuai dengan keinginan konsumen. 
Tabel 6. Penilaian responden terhadap tingkat kepentingan (Y) dan tingkat kinerja (X) serta tingkat kepuasan (TKi) pelayanan di Geo Coffee

\begin{tabular}{|c|c|c|c|c|c|c|}
\hline No & Atribut & $\mathrm{Xi}$ & $\bar{X}$ & Yi & $\bar{Y}$ & $\begin{array}{l}\text { Tki } \\
(\%)\end{array}$ \\
\hline 1 & $\begin{array}{l}\text { Kecepatan dalam merespon keluhan dan } \\
\text { permasalahan pelanggan }\end{array}$ & 420 & 4.62 & 349 & 3.84 & 120.34 \\
\hline 2 & Desain interior kafe & 421 & 4.63 & 353 & 3.88 & 119.26 \\
\hline 3 & $\begin{array}{l}\text { Pengetahuan karyawan terhadap menu } \\
\text { ataupun produk yang ditawarkan }\end{array}$ & 414 & 4.55 & 352 & 3.87 & 117.61 \\
\hline 4 & $\begin{array}{l}\text { Kemampuan komunikasi karyawan yang } \\
\text { baik dan mudah dimengerti }\end{array}$ & 413 & 4.59 & 353 & 3.88 & 117.00 \\
\hline 5 & Akses internet wifi & 413 & 4.54 & 365 & 4.01 & 113.15 \\
\hline 6 & Penampilan karyawan & 410 & 4.51 & 408 & 4.48 & 100.49 \\
\hline 7 & Kondisi lingkungan kafe yang bersih & 419 & 4.60 & 417 & 4.58 & 100.48 \\
\hline 8 & $\begin{array}{l}\text { Kepedulian terhadap masalah yang } \\
\text { dialami pelanggan }\end{array}$ & 409 & 4.49 & 409 & 4.49 & 100.00 \\
\hline 9 & $\begin{array}{l}\text { Kesungguhan dalam merespon dan } \\
\text { melayani pelanggan }\end{array}$ & 412 & 4.53 & 412 & 4.53 & 100.00 \\
\hline 10 & $\begin{array}{l}\text { Peralatan dan pelengkapan yang } \\
\text { digunakan sesuai standar }\end{array}$ & 338 & 4.10 & 357 & 4.24 & 96.73 \\
\hline 11 & $\begin{array}{l}\text { Keamanan dan kenyamanan pelanggan } \\
\text { pada saat berada di kafe }\end{array}$ & 334 & 3.71 & 354 & 3.92 & 94.68 \\
\hline 12 & Ketepatan penyajian menu & 339 & 3.67 & 362 & 3.89 & 94.35 \\
\hline 13 & $\begin{array}{l}\text { Kesamaan dalam memperlakukan } \\
\text { pelanggan }\end{array}$ & 332 & 3.73 & 355 & 3.98 & 93.65 \\
\hline 14 & $\begin{array}{l}\text { Kesopanan dan keramahan karyawan } \\
\text { dalam melayani pelanggan }\end{array}$ & 336 & 3.65 & 406 & 3.90 & 93.52 \\
\hline 15 & $\begin{array}{l}\text { Kemampuan dalam menjelaskan } \\
\text { ataupun memberikan informasi yang } \\
\text { dibutuhkan pelanggan }\end{array}$ & 333 & 3.69 & 410 & 4.46 & 82.76 \\
\hline 16 & $\begin{array}{l}\text { Proses pembuatan menu pesanan } \\
\text { dilakukan dengan cepat }\end{array}$ & 335 & 3.66 & 413 & 4.51 & 81.22 \\
\hline 17 & $\begin{array}{l}\text { Kesigapan dan daya tanggap pelayan } \\
\text { dalam memenuhi kebutuhan pelanggan }\end{array}$ & 335 & 3.68 & 415 & 4.54 & 81.11 \\
\hline 18 & $\begin{array}{l}\text { Kepercayaan diri karyawan dalam } \\
\text { melakukan pelayanan }\end{array}$ & 333 & 3.68 & 416 & 4.56 & 80.72 \\
\hline \multirow[t]{2}{*}{19} & $\begin{array}{l}\text { Pelayan menangani konsumen sesuai } \\
\text { kebutuhan }\end{array}$ & 334 & 3.66 & 418 & 4.57 & 80.05 \\
\hline & & & 4.10 & & 4.24 & 96.73 \\
\hline
\end{tabular}

Berdasarkan Tabel 6, Atribut dengan tingkat kepuasan atau tingkat kesesuaian tertinggi adalah kecepatan dalam merespon keluhan dan permasalahan pelanggan dengan tingkat kesesuaian sebesar 120,34\% yang berarti kinerja Geo Coffee melebihi kepentingan konsumen. Atribut dengan tingkat kesesuaian terendah adalah Pelayan menangani konsumen sesuai kebutuhan dengan tingkat kesesuaian sebesar $80,05 \%$ yang berarti kinerja Geo Coffee perlu diperbaiki karena belum memenuhi keinginan konsumen. 


\section{Tingkat Kepuasan Konsumen untuk Kualitas Produk}

Tingkat kepuasan konsumen untuk kualitas produk dapat di lihat pada Gambar 7 dan Tabel 12. Atribut-atribut yang berada di Kuadran A merupakan atribut yang dianggap penting oleh responden namun kinerja yang di terima dinilai masih kurang oleh konsumen. Atribut-atribut yang terdapat pada kuadran ini merupakan atribut yang menjadi prioritas untuk ditingkatkan dalam rangka mememuhi kenginan konsumen. Berdasarkan Tabel 7, bila dilihat secara persentase, Kuadran A memiliki nilai $0 \%$ yang artinya effort yang dilakukan perusahaan untuk meningkatkan kepuasan konsumen tidaklah terlalu besar. Atribut-atribut yang berada di kuadran B merupakan atribut yang dianggap penting oleh responden dan kinerja yang diterima dalam pelaksanaannya dinilai sudah sesuai dengan harapan konsumen. Ada dua (2) atribut atau 20\% yang masuk dalam kuadran ini sehingga perusahaan harus mampu menjaga konsistensi dari kedua atribut tersebut.

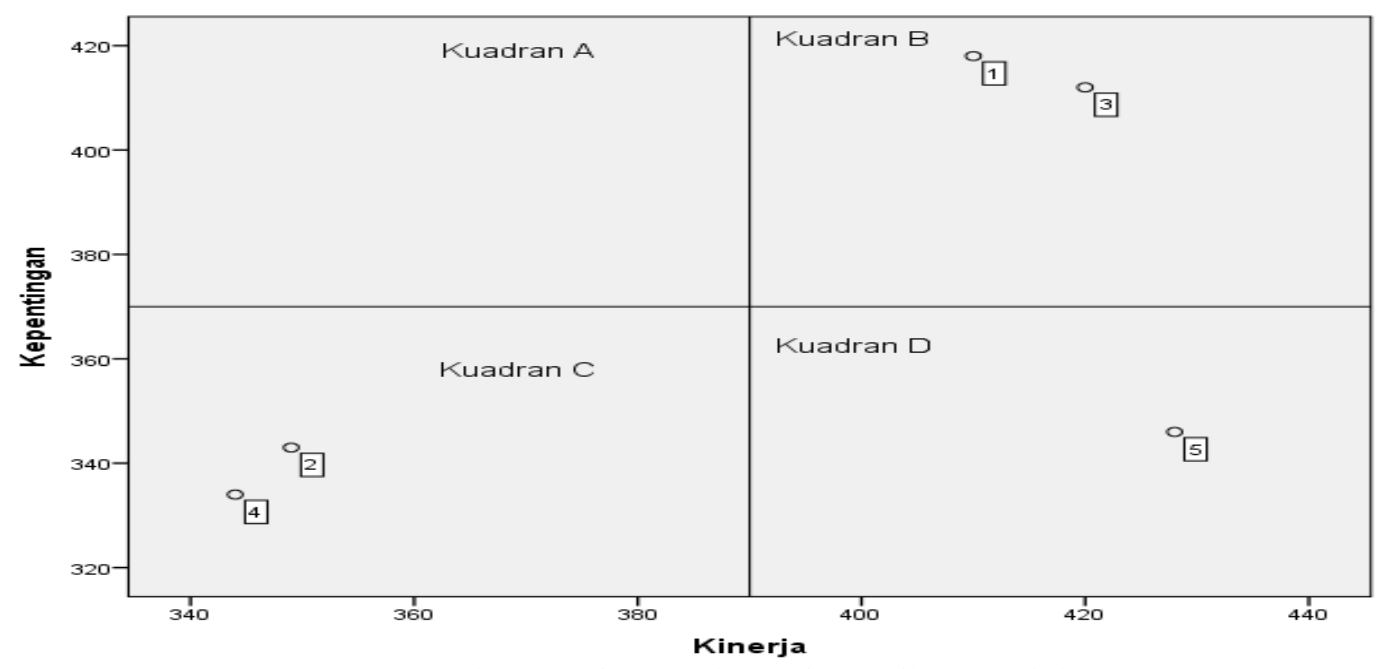

Gambar 1. Diagram kartesius atribut produk

Tabel 7. Deskripsi posisi kartesius atribut produk

\begin{tabular}{llcccc}
\hline No & Posisi Cartesius & $\begin{array}{c}\text { Jumlah } \\
\text { Atribut }\end{array}$ & Persentase & $\begin{array}{c}\text { Atribut No: } \\
\text { (Berdasarkan } \\
\text { Tabel 5) }\end{array}$ & Keterangan \\
\hline 1 & Kuadran A & 0 & $0 \%$ & - & - \\
2 & Kuadran B & 2 & $20 \%$ & 1 dan 3 & $\mathrm{X}>\bar{X}, \mathrm{Y}>\bar{Y}$ \\
3 & Kuadran C & 2 & $20 \%$ & $4 \operatorname{dan} 2$ & $\mathrm{X}<\bar{X}, \mathrm{Y}<\bar{Y}$ \\
4 & Kuadran D & 1 & $10 \%$ & 5 & $\mathrm{X}>\bar{X}, \mathrm{Y}<\bar{Y}$ \\
\hline
\end{tabular}

Atribut-atribut yang berada di kuadran $\mathrm{C}$ merupakan atribut yang dianggap kurang penting oleh responden dan kinerja yang diterima dalam pelaksanaannya juga biasa saja. Ada dua (2) atribut atau $20 \%$ yang masuk dalam kuadran ini, antara lain adalah rasa kopi seimbang antara pahit, manis, dan asam dan unsure rasa manis pada kopi. Atribut-atribut yang berada di kuadran D merupakan atribut yang dianggap kurang penting oleh responden namun kinerja yang diterima dalam pelaksanaannya sudah sangat baik. Hanya ada satu atribut dalam kuadran ini yakni rasa kopi memiliki ciri khas. Hal ini berarti Geo Coffee harus mempertahankan kinerja dari atribut-atribut ini namun jangan terlalu berlebihan dalam pelaksanaannya.

\section{Tingkat Kepuasan Konsumen untuk Kualitas Pelayanan}

Tingkat kepuasan konsumen untuk kualitas pelayanan dapat dilihat pada Gambar 2 dan Tabel 8. Atribut-atribut yang berada di kuadran A merupakan atribut yang dianggap penting oleh responden. Namun kinerja yang diterima dalam pelaksanaannya dinilai kurang oleh konsumen. Ada enam (6) atribut atau $32 \%$ dalam kuadran ini antara lain adalah (1) pelayan menangani konsumen sesuai 
kebutuhan, (2) kecepatan waktu penyajian, (3) kepercayaan diri karyawan dalam melakukan pelayanan, (4) Kemampuan dalam menjelaskan ataupun memberikan informasi yang dibutuhkan pelanggan, (5) Kesigapan dan daya tanggap pelayan dalam memenuhi kebutuhan pelanggan dan (6) Peralatan dan pelengkapan yang digunakan sesuai standar. Bila dibandingkan dengan atribut produk yang ada pada Kuadran A, pada atribut pelayanan effort yang dilakukan oleh Geo Coffee lebih besar dalam rangka memenuhi keinginan konsumen

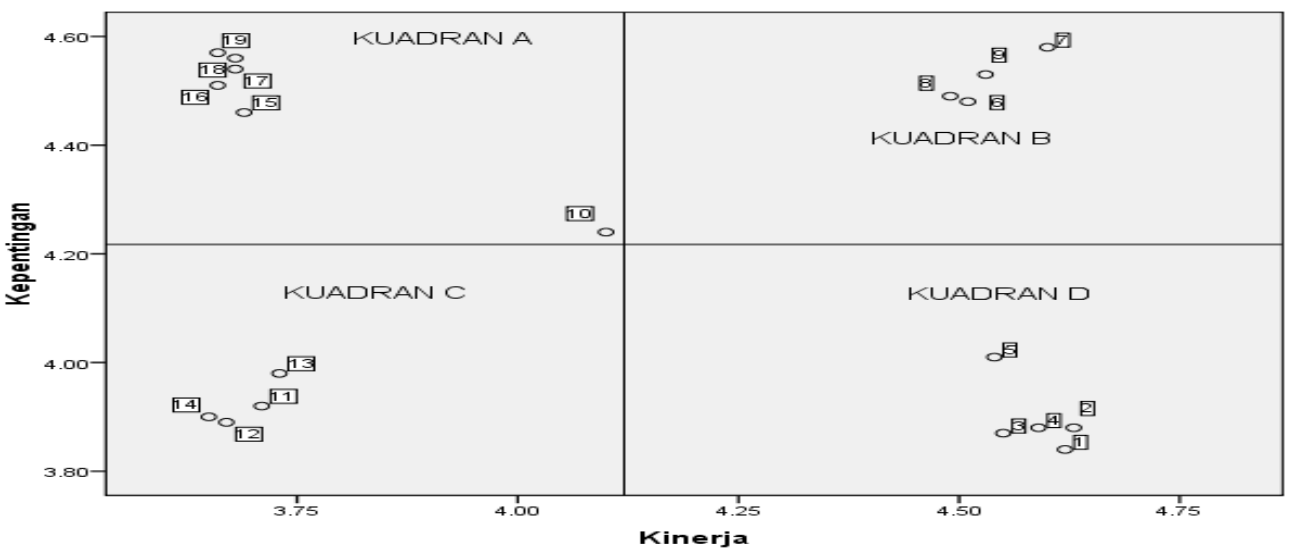

Gambar 2. Diagram kartesius untuk atribut pelayanan

Tabel 8. Deskripsi posisi kartesius atribut pelayanan

\begin{tabular}{llcccc}
\hline No & Posisi Cartesius & $\begin{array}{c}\text { Jumlah } \\
\text { Atribut }\end{array}$ & Persentase & $\begin{array}{c}\text { Atribut No: } \\
\text { (Berdasarkan } \\
\text { Tabel 6) }\end{array}$ & Keterangan \\
\hline 1 & Kuadran A & 6 & $32 \%$ & $\begin{array}{c}10,15,16,17, \\
18, \text { dan } 19\end{array}$ & $\mathrm{X}<\bar{X}, \mathrm{Y}>\bar{Y}$ \\
2 & Kuadran B & 4 & $21 \%$ & $6,7,8$ dan 9 & $\mathrm{X}>\bar{X}, \mathrm{Y}>\bar{Y}$ \\
3 & Kuadran C & 4 & $21 \%$ & $11,12,13$ dan & $\mathrm{X}<\bar{X}, \mathrm{Y}<\bar{Y}$ \\
4 & Kuadran D & 5 & $26 \%$ & $1,2,3,4$ dan 5 & $\mathrm{X}>\bar{X}, \mathrm{Y}<\bar{Y}$ \\
\hline & Jumlah & 19 & $100 \%$ & & \\
\hline
\end{tabular}

Atribut-atribut yang berada di kuadran B merupakan atribut yang dianggap penting oleh responden dan kinerja yang diterima dalam pelaksanaannya dinilai sudah sesuai dengan keinginan konsumen. Ada empat (4) atribut atau $21 \%$ yang masuk dalam Kuadran B yang berarti Geo Coffee harus mampu mempertahankan kinerja dari atribut ini demi menjaga kepuasan konsumen. Atributatribut yang berada di kuadran $\mathrm{C}$ merupakan atribut yang dianggap kurang penting oleh responden dan kinerja yang diterima dalam pelaksanaannya juga biasa saja. Ada empat (4) atribut atau $21 \%$ yang masuk dalam Kuadran C, atribut-atribut tersebut adalah: (1) ketepatan penyajian menu, (2) Kesamaan dalam memperlakukan pelanggan, (3 Kesopanan dan keramahan karyawan dalam melayani pelanggan , (4) keamanan dan kenyamanan pelanggan pada saat berada di kafe

Atribut yang berada di kuadran D merupakan atribut yang dianggap kurang penting oleh responden namun kinerja yang diterima dalam pelaksanaannya dinilai sudah sangat baik oleh konsumen. Sebanyak lima (5) atribut atau 26\% masuk dalam Kuadran ini. Atribut tersebut adalah (1) desain interior kafe, (2) akses internet wifi, (3) kemampuan komunikasi karyawan, (4) kecepatan dalam merespon keluhan dan permasalahan pelanggan, dan (5) pengetahuan karyawan terhadap menu ataupun produk yang ditawarkan. Hal ini berarti Geo Coffee harus mempertahankan kinerja dari atribut-atribut ini namun jangan terlalu berlebihan dalam pelaksanaannya 


\section{KESIMPULAN DAN SARAN}

\section{Kesimpulan}

Berdasarkan analisis yang telah dilakukan sebelumnya, dapat disimpulkanbeberapa hal sebagai berikut :

1. Atribut kualitas produk yang dianggap penting diurutkan dari besar ke kecil: rasa kopi, aroma kopi, aftertaste, konsistensi, kualitas pelayanan yang dianggap penting diurutkan dari besar sampai kecil: reliability, tangible, empaty, responsiveness, assurance.

2. Tingkat kinerja kualitas produk diurut berdasarkan 3 nilai tertinggi adalah sebagai berikut rasa kopi, keasaman rasa, aroma kopi. Tingkat kinerja kualitas pelayanan diurut berdasarkan 3 nilai tertinggi adalah sebagai berikut desain interior, responship, kebersihan.

3. Tingkat kepuasan konsumen terhadap kualitas produk tertinggi : unsur aroma kopi $(101,95 \%)$ dan tingkat kesesuaiannya terendah: konsistensi rasa kopi setiap penyajian $(82,52 \%)$, untuk tingkat kepuasan konsumen terhadap kualitas pelayanan tertinggi: kecepatan dalam merespon keluhan $(120,34 \%)$ tingkat kesesuaian terendah: pelayan menangani konsumen sesuai kebutuhan $(80,05 \%)$.

4. Atribut-atribut yang perlu mendapatkan prioritas untuk kualitas produk adalah: rasa kopi dan aroma kopi, untuk kualitas pelayanan: kemampuan dalam menjelaskan kesamaan dalam memperlakukan pelanggan.

\subsection{Saran}

Saran dari penelitian ini adalah perlu dilakukannya perbaikan oleh pihak Geo Coffee terhadap atribut-atribut kualitas produk pada kuadran B diagram kartesius yakni: aroma kopi dan formulasi kopi serta perbaikan pada atribut kualitas pelayanan yang berada pada kuadran B diagram kartesius yakni: Penampilan karyawan, kondisi lingkungan kafe, kepedulian terhadap masalah yang dialami pelanggan ,kesungguhan dalam merespon dan melayani pelanggan

\section{DAFTAR PUSTAKA}

Ainy, A.M., dan Fajar, N.A. 2012. Importance Performance Analysis Pelayanan Jaminan Sosial Kesehatan di Puskesmas Swakelola Pembina.Jurnal Kesehatan Masyarakat Nasional 7 (3) : 105-110.

Aditya, W. I., Nocianitri, A. K., Yusasrini, A. L. N. 2016. Kajian Kandungan Kafein Kopi Bubuk, Nilai Ph Dan Karakteristik Aroma Dan Rasa Seduhan Kopi Jantan (Pea Berry Coffee) Dan Betina (Flat Beans Coffee) Jenis Arabika Dan Robusta. Jurusan Ilmu dan Teknologi Pangan, Fakultas Teknologi Pertanian, Universitas Udayana.

Damanik, A. P., Astuti , R., Silalahi, R. L .R. 2014. Analisis Kepuasan Konsumen Terhadap Kualitas Minuman Kopi dengan Metode Importance Performance Analysis (IPA) dan Customer Satisfaction Index (CSI) di Coffee Story Malang. Jurusan Teknologi Industri Pertanian. Universitas Brawijaya.

Dian, L. 2014. Analisis Persepsi Konsumen Menggunakan Metode Importance Performance Analysis Dan Customer Satisfaction Index. Jurnal Industri. Vol. 4.No. 2.Hal. 74 - 81

Ghozali, I. 2005.Aplikasi Analisis Multivarariate Dengan Program SPSS. Badan Penerbit Universitas Diponegoro Semarang. Semarang.

Haryanto, B. 2012. Prospek Tinggi Bertanam Kopi. Yogyakarta: Pustaka Baru Press.

Kerlinger, F. N andLee, H.B. 2000.Foundation of Behavioral Research (edisi terjemahan). Hartcourt College Publisher. New York. 
Omar, H. F. H., Saadan, B. K. D., Seman, B. K. P. 2015. Determining the Influence of the Reliability of Service Quality on Customer Satisfaction: The Case of Libyan E-Commerce Customers. Faculty of Science and Technology, Universiti Sains Islam Malaysia,

Panggabean, E. (2011). Buku Pintar Kopi. Jakarta: PT. Argo Media Utama

Qomariyah, N., Santosa I., Effendi M. 2014. Analisis Sikap Konsumen Dan Kinerja Atribut Kopi Bubuk Sido Luhur. (Studi Kasus Di Ukm Kopi Bubuk Sido Luhur, Kota Malang). Jurusan Teknologi Industri Pertanian, Fakultas Teknologi Pertanian, Univ. Brawijaya

Lodhita, H. E. 2014. Analisis Pengaruh Kualitas Pelayanan Terhadap Kepuasan Konsumen Menggunakan Metode IPA (Importance Performance Analysis) dan CSI (Customer Satisfaction Index) Studi Kasus pada Toko Oen, Malang.Skripsi. Jurusan Teknologi Industri Pertanian. Fakultas Teknologi Pertanian. Universitas Brawijaya.

Lucano, G. L. 2011. Analisis Pengaruh Kualitas Produk, Promosi, Dan Interior Terhadap Keputusan Pembelian Konsumen Di Restoran Imperial Lamian Tunjungan Plaza Surabaya. Manajemen Perhotelan, Universitas Kristen Petra, Surabaya, Indonesia

Rahayu, S. 2011. Karakteristik Mutu Biji Kopi pada Proses Dekafeinasi. Jurusan Teknologi Pertanian Fakultas Pertanian, Universitas Sriwijaya, Palembang.

Torey, R. J., Porajouw , O., Lolowang, T. 2016 . Analisis Tingkat Kepuasan Konsumen Terhadap Produk Kopi Dan Pelayanan Di Rumah Kopi Billy Cabang Megamas Manado. Jurusan AgriSosioekonomi. Universitas Sam Ratulangi.

Tjiptono, F. 2012, Pemasaran Strategik. Yogyakarta, ANDI 